\title{
The Effects of Conjugated Linoleic Acids on Cancer
}

\author{
Marko Dachev ${ }^{1, *}$, Jana Bryndová ${ }^{1}$, Milan Jakubek ${ }^{2}{ }^{\mathbb{D}}$, Zdeněk Moučka ${ }^{1}$ and Marian Urban $^{1}$ \\ 1 Food Research Institute Prague, 10200 Prague, Czech Republic; jana.bryndova@vupp.cz (J.B.); \\ zdenek.moucka@vupp.cz (Z.M.); marian.urban@vupp.cz (M.U.) \\ 2 Department of BIOCEV, First Faculty of Medicine, Charles University Prague, 25250 Vestec, Czech Republic; \\ milan.jakubek@lf1.cuni.cz \\ * Correspondence: marko.dachev@vupp.cz
}

Citation: Dachev, M.; Bryndová, J.; Jakubek, M.; Moučka, Z.; Urban, M. The Effects of Conjugated Linoleic Acids on Cancer. Processes 2021, 9, 454. https://doi.org/10.3390/ pr9030454

Academic Editor: Carla Vitorino

Received: 15 January 2021

Accepted: 25 February 2021

Published: 3 March 2021

Publisher's Note: MDPI stays neutral with regard to jurisdictional claims in published maps and institutional affiliations.

Copyright: (C) 2021 by the authors. Licensee MDPI, Basel, Switzerland. This article is an open access article distributed under the terms and conditions of the Creative Commons Attribution (CC BY) license (https:/ / creativecommons.org/licenses/by/ $4.0 /)$.

\begin{abstract}
Conjugated linoleic acids (CLA) are distinctive polyunsaturated fatty acids. They are present in food produced by ruminant animals and they are accumulated in seeds of certain plants. These naturally occurring substances have demonstrated to have anti-carcinogenic activity. Their potential effect to inhibit cancer has been shown in vivo and in vitro studies. In this review, we present the multiple effects of CLA isomers on cancer development such as anti-tumor efficiency, antimutagenic and anti-oxidant activity. Although the majority of the studies in vivo and in vitro summarized in this review have demonstrated beneficial effects of CLA on the proliferation and apoptosis of tumor cells, further experimental work is needed to estimate the true value of CLA as a real anti-cancer agent.
\end{abstract}

Keywords: conjugated linoleic acids (CLA); anti-cancer; anti-tumor; anti-mutagenic; anti-oxidant; proliferation; apoptosis

\section{Introduction}

Fatty acids are important elements of the human body, having biological, structural and maintenance roles. There is a great research of interest towards the fatty acids and its potential health benefits [1]. Depending on the presence or absence of the double bonds, fatty acids are classified into two major classes: saturated and unsaturated. Saturated fatty acids contain only single bonds, whereas unsaturated fatty acids contain double or triple bonds. Unsaturated fatty acids that contain two or more double bonds are referred to as polyunsaturated fatty acids (PUFA). There are various types of PUFA, classified by their chemical structure. The first type includes fatty acids which double bonds are separated by methylene group $\left(-\mathrm{CH}_{2-}\right)$, all found with cis configuration. This type of naturally occurring fatty acids are known as essential fatty acids. Common non-conjugated PUFA are linoleic or $\omega-6$ (9 cis, 12 cis-C18:2), found in nuts, seed and vegetable oils and $\alpha$-linolenic or $\omega-3$ (9 cis, 12 cis, 15 cis-C18:3), found in seed, oil of plants, fish and seafood. In the second type the double bonds have conjugated bonds and includes fatty acids in multiple positional (9 cis, 11 trans-C18:2 and 10 trans, 12 cis-C18:2) isomers known as conjugated fatty acids (CFA). A group of CFA, containing 18 carbons and 2 conjugated bonds are known as conjugated linoleic acids (CLA), those having 18 carbons and 3 double bonds are referred to as conjugated linolenic acids (CLNA) and those having 20 carbons and 5 double bonds are conjugated eicosapentaenoic acids (CEPA). A well-studied example of conjugated fatty acids is CLA.

CLA are naturally occurring isomers of fatty acids found in ruminant animal food products [2]. There are 28 known CLA isomers identified with different position (ranging from $\Delta 7, \Delta 9$ to $\Delta 12, \Delta 14$ ) of cis or trans geometry. The most common biological isomers are the cis-9, trans-11(c9,t11), which accounts for more than $80 \%$ of CLA isomers in dairy products and cis-12, trans-10 $(t 10, c 12)$, present in some ruminant fats [3]. The natural product of CLA is a mixture of two isomers: $c 9, t 11$ and $t 10, c 12$ available by partial 
hydrogenation of linoleic acid and/or isomerization of cis unsaturated fatty acids, using bacterial enzymes as catalysts (Figure 1) [4]. Many bacteria have been reported to convert free LA into CLA: Butyrivibrio fibrisolvens [5], Megasphaera elsdenii [6], Lactobacillus reuteri [7], L. acididophilus [8], L plantarum [9], and Bifidobacterium breve [10].



Figure 1. Structure of linoleic acid (LA), $c 9, t 11$ and $t 10, c 12-C L A$.

CLA is an essential, but minor component of fats that enters the human body primarily from the sources of dairy products and meat from ruminant animals [11]. The physiological properties of CLA have received considerable attention over the past few decades due to their documented health-promoting benefits and biological functions. The main health properties described of CLA include the reduction of carcinogenesis, diabetes, obesity and atherosclerosis in different animal and cell line studies [12]. Although CLA was firstly reported by Booth in 1935 in butter fat, one of the first health beneficial properties attributed to CLA was its anti-carcinogenic effects discovered in the late $70 \mathrm{~s}$ by Pariza et al. [13,14]. The CLA was described as an anti-carcinogen isolated from fried ground beef [14-16]. Since then, various studies (in vivo and in vitro) demonstrated that CLA could act by promoting the inhibitory effects on tumor cell growth [17]. However, the mechanisms of action through which CLA acts against cancer are not fully clear at present. Another important question is the dose and which isomer is necessary to bring the desired beneficial effects. In most of the studies, CLA mixture was demonstrated as a potential anti-cancer agent to regulate the tumor growth through different metabolic pathways and to alter lipid peroxidation, cell proliferation and apoptosis [18]. Some of the studies demonstrated the effective dose of a single isomer $c 9, t 11$-CLA, but not $t 10, c 12$-CLA [17-19]. Contrary to the initial studies, there have been few reports of CLA that did not show any inhibitory effects against cancer and even showed promotion on tumor progression [20].

The objective of this review is to summarize various reports on animals, cell models, as well as clinical studies, to provide an idea on the aspects of CLA anti-cancer benefits and its mechanisms of actions.

\section{Animal Models}

Pioneering research, done by Michal Pariza and colleagues, showed that the extracts of grilled ground beef exerted anti-mutagenic activity, and that the responsible anti-mutagen was CLA [21]. Feeding the mice with CLA developed only half the number of tumor formations and lowered the incidence of carcinogenesis [13-16,21]. Various animal studies 
reported the effects of CLA (synthetic or natural source) in vivo, demonstrating the CLA inhibition on initiation, promotion and progression of cancer [22]. Different animal models have been used to prove the inhibitory effects of CLA in different cancer developments (Table 1).

Table 1. Effects of conjugated linoleic acids (CLA) in carcinogenesis (animal models).

\begin{tabular}{|c|c|c|c|c|c|}
\hline $\begin{array}{l}\text { Cancer } \\
\text { Type }\end{array}$ & Inducer & Animal & CLA Source & Effects & Reference \\
\hline Colon & $\mathrm{DMD}^{1}$ & SD rats & CLA mixture & $\begin{array}{l}\text { Incresed apoptotic index, } \\
\text { lower number of tumors. }\end{array}$ & Park et al. [23] \\
\hline Colon & $\mathrm{AOM}^{2}$ & SD rats & CLA mixture & $\begin{array}{l}\text { Incresed apoptosis, and } \\
\text { activity of Caspase- } 3 \text {. }\end{array}$ & Shiraishi et al. [24] \\
\hline Colon & Crypt fission & Apc $(\min /+)$ mice & $\begin{array}{r}c 9, t 11-\mathrm{CLA} \\
t 10, c 12-\mathrm{CLA}\end{array}$ & $\begin{array}{l}\text { Decrease polyp size. } \\
\text { Increase polyp size. }\end{array}$ & Mandir et al. [25] \\
\hline Colon & Unhealthy diet & Apc $(\min /+)$ mice & CLA mixture & No effect. & Petrik et al. [26] \\
\hline $\begin{array}{l}\text { Colon and } \\
\text { pulmonary }\end{array}$ & $\mathrm{NMU}^{3}$ & BALB/c mice & $\begin{array}{r}c 9, t 11-\mathrm{CLA} \\
t 10, c 12-\mathrm{CLA}\end{array}$ & $\begin{array}{l}\text { Inhibit cancer cell migration, } \\
\text { reduced pulmonary nodules. }\end{array}$ & Soel et al. [27] \\
\hline Colon & $\mathrm{AOM}$ & SD rats & $c 9, t 11-\mathrm{CLA}$ & $\begin{array}{c}\text { Inhibit aberrant crypts, } \\
\text { enhanced killer cell activiy. }\end{array}$ & $\begin{array}{l}\text { Nichenametla et al. } \\
\text { [28] }\end{array}$ \\
\hline Colon & $\mathrm{DMH}^{4}$ & SD rats & CLA mixture & $\begin{array}{l}\text { Reduced tumor incidence, } \\
\text { increase apoptosis. }\end{array}$ & Kim et al. [29] \\
\hline Colon & AOM & BALB/c mice & CLA mixture & $\begin{array}{l}\text { Decreased metastatic foci, } \\
\text { activation PPRn. }\end{array}$ & Sasaki et al. [30] \\
\hline Mammary & DMBA $^{5}$ & SD rats & CLA mixture & No effect. & Ip et al. [31] \\
\hline $\begin{array}{l}\text { Mammary and } \\
\text { breast }\end{array}$ & DMBA & SD rats & CLA mixture & Inhibit PUFA oxidation. & Bialek et al. [32] \\
\hline Breast & DMBA & SCID rats & CLA mixture & Reduced tumor growth. & Visonneau et al. [33] \\
\hline Mammary & DMBA & BALB/c mice & CLA mixture & $\begin{array}{l}\text { Prolong tumor latency, } \\
\text { decresed tumor burden. }\end{array}$ & Hubbard et al. [34] \\
\hline Breast & DMBA & BALB/c mice & $c 9, t 11-$ CLA & $\begin{array}{l}\text { Reduced tumor growth in } \\
\text { conjugate with gemcitabine. }\end{array}$ & Tao et al. [35] \\
\hline Mammary & $\mathrm{MNU}^{6}$ & $\mathrm{SD}$ rats & $c 9, t 11-$ CLA & $\begin{array}{l}\text { Decressed tumor mass per } \\
\text { animal. }\end{array}$ & $\begin{array}{c}\text { Lavillonneiere et al. } \\
\text { [36] }\end{array}$ \\
\hline $\begin{array}{l}\text { Mammry and } \\
\text { breast }\end{array}$ & DMBA & SD rats & $c 9, t 11-\mathrm{CLA}$ & $\begin{array}{l}\text { Decreased tumor weight and } \\
\text { volume. }\end{array}$ & Zeng et al. [37] \\
\hline Breast & MNU & SD rats & CLA mixture & $\begin{array}{l}\text { Decresed terminal and bud } \\
\text { cell density. }\end{array}$ & Ip et al. [38] \\
\hline Prostate & DMBA & SCID mice & CLA mixture & Inhibit cancer cell grovth. & Cesano et al. [39] \\
\hline Prostate & $\mathrm{PhIP}^{7}$ & Big blue rats & CLA mixture & $\begin{array}{l}\text { Inhibit the formation of } \\
\text { PhIP } \rightarrow \text { DNA. }\end{array}$ & Yang et al. [40] \\
\hline Prostate & AIN-76A diet & Copenhagen rats & CLA mixture & $\begin{array}{l}\text { Apoptotic activity and } \\
\text { citotoxycity. }\end{array}$ & Jung et al. [41] \\
\hline Prostate & PhIP & Copenhagen rats & CLA mixture & $\begin{array}{c}\text { Not beneficiary alone, effect } \\
\text { with isoflavone. }\end{array}$ & Cohen et al. [42] \\
\hline Pancreas & $\mathrm{BOP}^{8}$ & Syrian hamster & CLA mixture & No effect. & Kilian et al. $[43,44]$ \\
\hline Liver & $\mathrm{AOM}$ & Male F344 rats & $c 9, t 11-\mathrm{CLA}$ & $\begin{array}{l}\text { Tumor inhibition, increse } \\
\text { expression of PPRn. }\end{array}$ & Kohno et al. [45] \\
\hline Liver & AOM & Donryu rats & CLA mixture & $\begin{array}{l}\text { Induce hepatic lipid } \\
\text { peroxidation and } \\
\text { accumulation. }\end{array}$ & Yamasaki et al. [46] \\
\hline
\end{tabular}

${ }^{1}$ (DMD): 1,2-dimethylhydrazin; ${ }^{2}$ AOM: azoxymethane; ${ }^{3}$ NMU: N-nitroso-N-methylurea; ${ }^{4}$ DMH: 1,2-dimethylhydrazine; ${ }^{5}$ DMBA: 7,12-dimethylbenz(a)anthracene; ${ }^{6} \mathrm{MNU}$ : N-methyl-nitrosourea ${ }^{7}$ PhIP: 2-Amino-1-methyl-6-phenylimidazo[4,5-b]pyridine; ${ }^{8}$ BOP: Nnitrosobis-2-oxopropylamine. 


\subsection{Colon Cancer}

In rodents, CLA induced the reduction of colon carcinoma by induction of apoptosis. The mechanism of CLA proposed was examined on Sprague-Dawley (SD) rats fed diary with $1 \%$ CLA to suppress the colon carcinogenesis in 1,2-dimethylhydrazin (DMD)pretreated animals. The incidence of colon tumor was significantly lower in the rats fed with 1\% CLA compared to the control rats. The results showed decrease of the potent inflammatory mediator $\mathrm{PGE}_{2}$ and increase on the ratio of the apoptosis regulation protein Bax/Bcl-2 [23]. Shiraishi et al. indicated a study of cancerous rats by long-term feeding with beef tallow. The mixture of CLA isomers was used suppress colon carcinogenesis. The effects of CLA mixture was investigated, where the animal model was previously treated with azoxymethane (AOM). The results demonstrated that the mixture of $1 \%$ CLA in triglyceride form (CLA-TG) and 1\% CLA in free fatty acid form (CLA-FFA) had beneficial effects against colon cancer incidence. Although CLA-FFA was more superior on colon carcinogenesis, its precise mechanism of apoptosis was unclear [24]. The antineoplastic actions of different forms of CLA ( $c 9, t 11$ and $t 10, c 12$ isomers) were investigated on colon polyp development in the $\mathrm{Apc}^{(\mathrm{min} /+)}$ mice. The experimental group fed with the commercially form of $t 10, c 12$-CLA isomer was associated with inflammation-induced colon cancer by increasing the polyp diameter in the intestinal neoplasia through a proposed signaling pathway of the nuclear receptor peroxisome proliferator-activated receptor- $\gamma$ $(\operatorname{PPAR} \gamma)$. However, the naturally occurring isomer $c 9, t 11$ decreased the polyp number and did not increase the polyp size, suggesting that this isomer can work as a protective factor against colon cancer. Although the role of CLA in inhibiting carcinogenesis in the Apc ${ }^{(\mathrm{min} /+)}$ mice was proved, not all experiments have shown positive effects [25]. Petrik et al. demonstrated that an overdose of CLA can have counter effect on the mechanism in prevention of cancer, meaning it did not reduce tumorigenesis in a laboratory model of colon carcinogenesis [26]. Soel et al. investigated the colon cancer metastasis in $\mathrm{BALB} / \mathrm{c}$ mice put under diet containing both CLA isomers $c 9, t 11$ and $t 10, c 12$. The mice were injected with carcinoma cells (CT-26) and dietary fed with CLA containing $0.1 \% c 9$, $t 11 / t 10, c 12$ or no CLA at all for 4 weeks. It was found that, in vitro $c 9, t 11$-CLA was more effective in inhibiting the cancer cell migration. Presumably, t10, c12-CLA isomer was more effective against increasing the number of pulmonary modules. Interestingly, the diet containing both CLA isomers $c 9, t 11$ and $t 10, c 12$ was more effective against colon cancer cell metastasis in vivo [27]. More research is needed to explain the mechanisms by which the individual CLA isomers inhibit pulmonary metastasis and colon cancer. Another study examined the role of possible additive or synergistic action of purified $c 9, t 11$-CLA isomer with sphingomyelin (SPH) and butyrate (BTY) against colon cancer and modulation of immune functions in vivo in SD rats. The rats were injected with azoxymethane (AOM) and the combination of $c 9, t 11-\mathrm{CLA}$ with SPH and BTY showed that the mixture cannot act additively (or synergistically) to inhibit the development of aberrant crypts or to enhance immune functions. The CLA isomer alone had substantially higher destructive activity than the control group. The fact that all three compounds followed different pathways on biological effects like the induction of apoptosis, could result in antagonistic effects on cancer treatment [28]. Kim et al. investigated the reduction of colon tumor effects of CLA on DMH-induced carcinogenesis in rats. The CLA was supplemented with fish oil rich in $\omega-3$ fatty acids and the CLA influence resulted in decreasing eicosanoid (TXB2 and PGE2) levels in the colon mucous. The combination of CLA and $\omega-3$ successfully reduced the tumor incidence and increased the cell apoptosis. This response of sharing the same path of action needs to be further investigated [29]. Additional study on the beneficial effects of CLA against gastric and colon carcinogenesis tested on BALB/c mice inoculated with MKN28 and Colo320 cancer cells, resulted in decreasing of the number of metastatic foci into the peritoneal cavity administered by CLA intake [30]. 


\subsection{Breast and Mammary Cancer}

CLA was found to down-regulate cell proliferation in breast cancer. Ip C et al. demonstrated the beneficial effects of CLA combined with fat diet against developing of mammary tumors induced by a carcinogen 7,12-dimethylbenz(a)anthracene (DMBA). The rats were fed with $0.5 \%, 1 \%, 1.5 \%$ and $2 \%$ of CLA together with $2-12 \%$ of linoleate fat, starting from the carcinogen injection till the end of the experiment. The efficiency of tumor suppression by CLA was not affected by fat intake and neither CLA was replaced by linoleic or arachidonic acid in the mammary in the mammary tissue [31]. Bialek et al. also investigated the effects of CLA applied to breast cancer in rats initiated by carcinogenic agent DMBA. That study was related with the expression of cyclooxygenase 2 and prostaglandin receptor E2 in mammary tumor associated with different types of cancer. After the application of CLA isomers $(c 9, t 11$ and $t 10, c 12)$, the cancer morbidity was reduced [32]. Visonneau et al. reported that the intake of dietary 1\% CLA on the growth of human breast adenocarcinoma cells in severe combined immunodeficient (SCID) mice resulted in inhibition of breast cancer cells and prevention of metastatic spread into the lungs, peripheral blood and bone marrow. The tumor suppression was estimated by $30-73 \%$ at 14 weeks postinoculation [33]. Another report demonstrated the effects on CLA against metastasis of mammary tumors in rodents. The mice fed with $20 \%$ fat diets staring from 0.1 till $1 \%$ of CLA had a significant decrease of pulmonary tumor burden compared to mice treated with $0 \%$ CLA. The decrease of the number of the pulmonary nodules was effective as indomethacin, a known anti-inflammatory drug [34]. In another study, a novel-prodrug Gemcitabine (GEM)-CLA was developed to investigate the anticancer activity on mice breast tumor. Gemcitabine is a known chemotherapy medication used to treat various types of cancer. However, its hydrophilic properties did not allow a free transport across the cell membrane; therefore, high drug resistance was found in nucleoside transporters deficiency patients. Under these circumstances, GEM-CLA conjugate was synthesized by chemically linking the $\mathrm{N}^{4}$ amino groups of GEM with CLA. Tao et al. studied the combination of chemotherapy drug GEM-CLA isomers as a promising medication against cancer in future. The results showed higher prevention of tumor cells growth compared to the unmodified GEM. The evidence indicated that this new prodrug had a significant plasma stability and superior anti-cancer effect which was previously consistent with the observations in vitro [35]. Dietary $c 9$, t11-CLA treatment has been shown to effectively reduce the mammary tumor growth [36]. The rats were introduced with mutagenic compound methylnitrosourea (MNU) and fed on oil based diet separated into three groups. In the first group the rats were supplemented with $1 \%$ pure 9c, 11t-CLA isomer, in the second group the rats were fed with 1\% CLA isomer mixture and the third group were the rats control group supplemented with free fatty acids prepared from the sunflower oil. The results showed that there was about $45 \%$ increase of mammary tumor inhibition in the two CLA groups. The chemically prepared fraction enriched in $c 9, t 11$-CLA was evaluated to reduce the tumor mass and had anticarcinogenic properties [37]. Another study of the dietary isomer of $c 9, t 11$ that showed preventive effect against breast cancer by decreasing the tumor weight and volume, and reducing the tumor incidence in female SD rats up to $50 \%$ [38]. The study was inspired by previously reported inhibitory effects on enriched butter with $c 9, t 11$-CLA against breast cancer [39]. The rats were injected with DMBA carcinogen. The $c 9, t 11$ isomer enriched from butter reduced the breast cancer progression by affecting the level of hormonal receptor and cell proliferation. Following, the expression of the hormonal receptor PR and the cell proliferation marker Ki-67 was decreased significantly with the treatment of $c 9, t 11$-CLA. The results indicated that the dietary isomer $c 9, t 11$ down regulated the hormonal receptor and had anti-proliferative effect against breast cancer in vivo.

\subsection{Prostate Cancer}

Cesano et al. reported the opposite impact of 1\% CLA in the diet vs. 1\% LA on prostate cancer in mice. In this study, the immunodeficient (SCID) mice were inoculated 
with metastatic cancer cells (DU-145) for 14 weeks. The experimental model of mice fed with the CLA-supplemented diet resulted in smaller local tumors growth and reduction in metastases. However, the SCID mice fed with LA-supplemented or regular diet displayed bigger tumor load [39]. CLA effects against prostate cancer in vivo were reported in another study. Yang et al. demonstrated that CLA inhibits the 2-Amino-1-methyl-6phenylimidazo[4,5-b]pyridine (PhIP)-induced prostate carcinogenesis. PhIP is a potent mutagen that induces tumor in prostate of male rats. Mixture of $c 9, t 11-C L A$ and $t 10$, c12-CLA was used to inhibit the prostate cancer in Big Blue ${ }^{\circledR}$ transgenic rats. The rats were fed with PhIP for 47 days and 1\% of CLA mixture was added after one week of exposure to PhIP. The degree of inhibitory effects of CLA against PhIP-induced mutagenicity were estimated at 38\% [40]. To confirm the apoptotic activity of CLA against prostate cancer, Jung et al. reported anticarcinogenic activity of selectively hydrogenated soybean oil (SHSO) that was modulated with high quantity of CLA [41]. The 5\% of dietary SHSO showed the best results to inhibit the prostate cancer in the rat model (Copenhagen rat), by an estimation of $80 \%$. On the other hand, not all cases in vivo have showed positive effects on the inhibition of prostate tumor cells. Isoflavone-rich soy protein isolate (SPI) and CLA did not inhibit the growth of R-3327-AT-1 rat prostate tumor cells inoculated into the Copenhagen rats. Furthermore, the combinations of SPI and CLA at the highest concentrations (20\% SPI and 1\% CLA) increased the tumor volumes over the controls. CLA alone had not effect on the prostate tumor growth [42].

\subsection{Pancreatic and Liver Cancer}

Few animal studies on pancreatic and liver tumor metastasis have been performed. Kilian et al. used an expe rimental model of chemically induced pancreatic carcinoma in Syrian hamster in order to evaluate the influence of CLA and LA on liver metastases. The impact of dietary CLA and LA on liver carcinogenesis and lipid peroxidation (LPO) was investigated in N-nitrosobis-2-oxopropylamine (BOP)-inoculated 60 hamsters for 12 weeks. Number, size and incidence of the liver tumors did not differ between LA and CLA dietary groups and there was no effect on the liver metastasis [43]. A following study investigated the incidence of pancreatic cancer and liver metastasis by a dietary fat intake of CLA and LA. 60 male hamsters were selected in 4 groups. The first and group received $0.9 \% \mathrm{NaCl}$ once a week, while the third and the fourth group were injected with (BOP) for 12 weeks. The results showed that CLA and LA did not influence the incidence of pancreatic carcinoma. However in both groups there was an increased activity of glutathion peroxidase and higher level of lipid peroxidation in pancreatic intratumoral tissue [44]. Kohno et al. investigated the chemopreventive effects of pomegranate seed oil (PGO) that contained $70 \%$ of $c 9, t 11$ CLA isomer, against colon carcinogenesis. Male F344 rats were given subcutaneous injections of AOM once a week for two weeks. The inhibition of colonic adenocarcinomas by PGO was associated with the increased dietary content of $c 9$, t11-CLA in the lipid fraction of colonic mucosa and liver [45]. Yamasaki et al. performed extensive studies on the role of CLA in Donryu rats, injected with hepatoma dRLh-84 cells. They demonstrated that CLA enhanced the cancer activity at a concentration of $2 \%$. The tumor weight was also higher than in the $0 \%$ CLA group. This response of CLA could have derived from the differences in dietary duration and isomer infusion [46].

\section{Cellular Models}

The studies with tumor-bearing animals gave us a considerable information on the cancer preventive role of CLA. The consumption of CLA was proved to be effective against different types of cancer in different animal species. However, there have been a greater number of studies in cell culture models investigating the benefits of CLA against carcinogenesis. In order to investigate further, we revised the most trivial studies in vitro on the chemoprotective properties of CLA (Table 2). 
Table 2. Effects of CLA in carcinogenesis (cellular models).

\begin{tabular}{|c|c|c|c|c|}
\hline $\begin{array}{l}\text { Cancer } \\
\text { Type }\end{array}$ & Cell Lines & CLA Source & Effects & Reference \\
\hline Colon & HТ-29 & CLA mixture & $\begin{array}{l}\text { Inhibition proliferation } \\
\text { by ErbB3 signaling. }\end{array}$ & Cho et al. [47] \\
\hline Colon & HT-29 & $\begin{array}{l}c 9, t 11-\mathrm{CLA} \\
t 10, c 12-\mathrm{CLA}\end{array}$ & $\begin{array}{l}\text { Inhibition proliferation } \\
\text { by ErbB3 signaling. }\end{array}$ & Cho et al. [48] \\
\hline Prostate and colon & HT-29, PC-3, MIP-101 & $\begin{array}{l}c 9, t 11-\mathrm{CLA} \\
t 10, c 12-\mathrm{CLA}\end{array}$ & Inhibition effect, caspase dependent. & Palombo et al. [49] \\
\hline Colon & Caco-2 & $\begin{array}{l}t 10, c 12-\text { CLA } \\
c 9, t 11-\text { CLA }\end{array}$ & $\begin{array}{l}t 10, c 12-C L A \text { inhibition proliferation. } \\
\text { Decresed insulin-like growth factor II } \\
\text { (IGF-II) expression. } \\
c 9, t 11-C L A \text { no effect. }\end{array}$ & Kim et al. [50] \\
\hline Colon & Caco-2 & $c 9, t 11-\mathrm{CLA}$ & $\begin{array}{c}\text { Antiproliferative effect, repressed } \\
\text { expresiion c-myc, cyclin D1 in a PPARn }\end{array}$ & Lampen et al. [51] \\
\hline Colon & HT-29 & CLA mixture & $\begin{array}{l}\text { Induced cell cycle arrest at } \mathrm{G}_{0} / \mathrm{G}_{1} \\
\text { phase }\end{array}$ & Lim et al. [52] \\
\hline Gastric & SGS-7901 & $c 9, t 11-\mathrm{CLA}$ & $\begin{array}{l}\text { Reduced adhesion. Increased the level } \\
\text { of ECD and } \alpha \text {-catenin. } \\
\text { Decrease ICAM-1 and VCAM-1 }\end{array}$ & Chen et al. [53] \\
\hline Breast & $\begin{array}{c}\text { MCF-7, } \\
\text { MDA-MB-231- ER } \alpha\end{array}$ & CLA mixture & $\begin{array}{l}\text { Induced cell apoptosis by caspase } \\
\text { activity. }\end{array}$ & $\begin{array}{c}\text { Wang et al. [54], Sorenmo } \\
\text { et al. [55] }\end{array}$ \\
\hline Breast & MCF-7 & $\begin{array}{l}c 9, t 11-\mathrm{CLA} \\
t 10, c 12-\mathrm{CLA}\end{array}$ & $\begin{array}{c}c 9, t 11-\text { CLA more effective suppress } \\
\text { growth. } \\
t 10, c 12 \text {-CLA less effective. }\end{array}$ & O'Shea et al. [56] \\
\hline Breast & MCF-7 & $\begin{array}{l}\text { c9, } t 11-\text { CLA } \\
t 9, t 11-\text { CLA } \\
t 10, c 12-\text { CLA }\end{array}$ & $\begin{array}{c}t 9, t 11-C L A \text { induced apoptosis, } \\
\text { incresed mMRA levels of LXR genes. } \\
c 9, t 11-C L A \text { and } t 10, c 12-C L A \text { less } \\
\text { potent. }\end{array}$ & El Roz et al. [57] \\
\hline Breast & MDA-MB-231 & CLA mixture & $\begin{array}{l}\text { ERK reduction and upregulation of } \\
\text { pro-apoptotic protein Bak }\end{array}$ & Miglietta et al. [58] \\
\hline Breast & MCF-7, MDA-MB-231 & CLA mixture & $\begin{array}{l}\text { Inhibition cell cycle, } \\
\text { c-myc expression. }\end{array}$ & Durgam et al. [59] \\
\hline Breast & MCF-7 & $\begin{array}{l}\text { CLA mixture } \\
\text { LA }\end{array}$ & $\begin{array}{l}\text { Inhibition on growth. } \\
\text { Stimulation of growth. }\end{array}$ & Park et al. [60] \\
\hline Breast & MCF-10A & $\begin{array}{l}t 9, t 11-\mathrm{CLA} \\
t 10, t 12-\mathrm{CLA} \\
c 9, t 11-\mathrm{CLA}\end{array}$ & $\begin{array}{l}\text { The anti-promotional activity of } t 9, t 11 \\
\text { and } t 10, t 12-C L A \text { were less potent than } \\
\qquad 9, t 11-C L A .\end{array}$ & Rakib et al. $[61,62]$ \\
\hline Prostate & DU145 & $\begin{array}{l}t 10, c 12-\mathrm{CLA} \\
c 9, t 11-\mathrm{CLA}\end{array}$ & $\begin{array}{l}t 10, c 12-C L A \text { inhibited the G1-S cell } \\
\text { cycle progression. } \\
c 9, t 11-\text { CLA no effect. }\end{array}$ & Kim et al. [63] \\
\hline Prostate & PC-3 & $\begin{array}{l}t 10, c 12-\text { CLA } \\
c 9, t 11-\text { CLA }\end{array}$ & $\begin{array}{l}t 10, c 12-\text { CLA apoptosis and cell cycle } \\
\text { control. } \\
c 9, t 11-C L A-R e g u l a t i o n \text { of genes for } \\
\text { arachidonic acid metabolism. }\end{array}$ & Ochoa et al. [64] \\
\hline Liver & dRLh-84 & $\begin{array}{l}c 9, t 11-\mathrm{CLA} \\
t 10, c 12-\mathrm{CLA}\end{array}$ & Different cytotoxic effects. & Yamasaki et al. $[65,66]$ \\
\hline Liver & SK-HEP-1 & CLA mixture & $\begin{array}{c}\text { Increased PPAR } \alpha \text { and proapoptotic } \\
\text { proteins. Activating apoptotic } \\
\text { pathways. }\end{array}$ & Muzio et al. [67] \\
\hline Liver & HepG2 & $\begin{array}{l}c 9, t 11-\mathrm{CLA} \\
t 10, c 12-\mathrm{CLA}\end{array}$ & $\begin{array}{l}\text { Inhibited cell proliferation and induced } \\
\text { apoptotic cell death under hypoxia. }\end{array}$ & Yamasaki et al. [68] \\
\hline Skin & HEL-30 & $\begin{array}{l}\text { Radioactive }\left(1-{ }^{14} \mathrm{C}\right) \\
\text { CLA }\end{array}$ & Partial inhibition of tumor promotion. & Liu et al. [69] \\
\hline
\end{tabular}

\subsection{Colon Cancer}

CLA has demonstrated beneficial effects to inhibit proliferation and induce apoptosis in HT-29, MIP-101 and Caco-2 colon cancer cells. Cho et al. examined the influence of 
CLA isomers on the ErbB3 signaling pathway, where HT-29 cells were cultured in the presence of a soluble secreted growth factor heregulin. It was demonstrated that CLA inhibited cell proliferation and stimulated apoptosis in colon carcinoma cell lines HT-29 [47]. An additional study showed the influence of $t 10, c 12$-CLA isomer on apoptosis and cell proliferation via modulation of the epidermal growth factor receptor ErbB3 that led to inhibition of PI3/Akt activation [48]. Another study confirmed the antiproliferative effects of $t 10, c 12-C L A$ in two colorectal (HT-29, MIP-101) and prostate (PC-3) carcinoma cells. The effects of $c 9, t 11-C L A$ isomer had weaker effects against prostate cancer comparing to the other isomer and no inhibitory effects in the gastrointestinal cells [49]. Kim et al. also studied the potential properties of the two main CLA isomers against colon cancer cells Caco-2, in vitro. The results indicated that $t 10, c 12$-CLA dose decreased the levels of the insulin growth factor (IGF-II) secretion and IGF-binding proteins, therefore inhibited the Caco-2 cell growth. The study concluded that only one isomer $110, c 12$-CLA induced cell apoptosis and decreased DNA synthesis, whereas $c 9, t 11$-CLA had no effect [50]. Nevertheless, some studies have showed inhibitory effects of $c 9, t 11$-CLA isomer. Lampen et al. demonstrated the results of $c 9, t 11$-CLA against colon tumor progression. The study revealed that in a dose ranging from 10-200 $\mu \mathrm{mol} / \mathrm{L}$ the chemoprotective effects of CLA against colon cancer might be explained through the cellular and molecular effects of $c 9, t 11$-CLA based on the interaction with peroxisome proliferator-activated receptors (PPARs), and the expression of genes relevant to the APC-beta-catenin-TCF4 signaling pathway in HT-29 and Caco-2 colon cells [51]. Another group showed the therapeutic benefits of CLA against growth of tumor cells with tumor protein p53. The physiological concentration of CLA increased the induction of the cyclin dependent kinase (CDK) inhibitor p21(CIP1/WAF). Overall, CLA induced the cell cycle arrest mediated by the p21(CIP1/WAF) and inhibited the activities of the proliferating cell nuclear antigen (PCNA) [52]. Chen et al. studied the effects of $c 9, t 11-C L A$ on the migration of human gastrointestinal carcinoma cells (SGS-7901) via cyclooxygenase-2 (COX-2) pathway. The highest growth inhibition was measured to be at $82 \%$ and the lowest at $6 \%$. It resulted that $c 9, t 11-C L A$ isomer inhibited the adhesion and chemotaxis of SGS-7901 cancer cells [53].

\subsection{Breast and Mammary Cancer}

Several studies on CLA against breast cancer cells (MCF-7, MDA-MB-231) showed inhibitory effects mediated through different signaling pathways. Different isomer concentrations of $c 9, t 11$-CLA and $t 10, c 12$-CLA have been proved to suppress the growth of tumor cells and decrease the protein expression in malignant mammary cells [54,55]. It has been shown that bovine milk fat enriched with CLA was effective at inhibiting growth and stimulating peroxidation of MCF-7 cells. Incubation of the cancer cells with the $c 9, t 11$-CLA isomer for 8 days was more effective than incubation with the t10, c11-CLA isomer. The lowered number of cancer cells was related with the cytotoxic effects of the milk fat-bound CLA, consisting primarily of the $c 9, t 11$-CLA isomer [56]. Different results were encountered in the study of El Roz et al. The individual effects of three CLA isomers $(c 9, t 11-\mathrm{CLA}$, $t 9, t 11$-CLA and $t 10, c 12-C L A)$ were compared on the proliferation and apoptosis via Liver X Receptor (LXR) genes in MCF-7 breast cancer cells. It was been shown that $19, t 11$-CLA isomer activated the LXR target genes in MCF-7 breast cancer cells and the activation of the anti-tumoral effects was the strongest among the other CLA isomers [57]. CLA significantly inhibited the anti-proliferative activity of the MDA-MB-231 human breast cancer cell line and generated reduction of the cell proliferation. This study established an important statement that CLA reduced the cell proliferation through a mitochondrial and ERK/MAPK signaling pathway. The inhibitory activity of CLA was extended during the accumulation of the cells in the S phase and was associated with an inhibition of DNA replication [54]. It has been shown that the regulation of apoptosis, done by a group of proteins named B-cell lymphoma 2 (Bcl-2), was crucial for human's health. Miglietta et al. examined the effects of CLA on the initiation of apoptosis by Bcl-2 proteins in human breast tissues. The research was done on human breast adenocarcinoma cells (MDA-MB-231). 
The findings confirmed the anti-carcinogenic effects of CLA by inducing the apoptosis of MDA-MB-231 cells [58]. Another study examined the action of CLA as an inhibitor of the cancerous MCF-7 cells. Durgam et al. compared the inhibitory effects of MCF-7 cells between CLA and LA. The results showed that CLA inhibited expression of c-myc in MCF-7 cells by interfering with the hormone regulated mitogenic pathway. The cells treated with LA had lower percentage of inhibition [59]. In another study, CLA had cancer cell inhibitory effects on hormone responsive MCF-7 human breast cancer cells, whereas LA was found to be stimulatory. Prostaglandin E2 secretion was not influenced by LA or CLA [60]. CLA was reported to inhibit the cell proliferation of MCF-10a mammary epithelial cells. The cells were treated with 12-tetradecanoylphorbol-13-acetate (TPA). The protective effect of $c 9, t 11$-CLA was proved to block the TPA-induced gap of junctional intercellular communication (GJIC) in the MCF-10a cells. The $c 9$, t11-CLA isomer prevented the MEK-ERK signaling pathway. However, the mechanism by which $c 9, t 11-C L A$ inhibited the MCF-10a cells induced by TPA was unclear [61]. Further on, the study continued and anti-tumor effects of $t 9, t 11$-CLA, $t 10, t 12$-CLA, and $c 9, t 11$-CLA were tested on MCF-10A cells induced by TPA. The results were compared to the previously obtained data that $c 9, t 11$-CLA was more effective than $t 10, c 12$-CLA. The study concluded that $t 9, t 11$-CLA and $t 10, t 12$-CLA were equally powerful on MCF-10A cells, however with less efficacy than $c 9, t 11$-CLA. The superior efficacy of $c 9, t 11$-CLA in preventing the downregulation of GJIC was associated with the ability of MCF-10A cells to prevent connexin43 (Cx43) phosphorylation and reactive oxygen species (ROS) generation. The difference in CLA isomers efficiency could be explained by their structural difference [62].

\subsection{Prostate Cancer}

There are few studies that have indicated the effect of CLA isomers on prostate carcinoma cells lines (DU145 and PC-3). Kim et al. investigated the anti-cancer properties of two CLA isomers, $c 9, t 11$-CLA and $t 10, c 12$-CLA on DU145 cell growth. The treatment of carcinogenic DU145 cells with t10, c12-CLA showed an inhibition of the G1-S cell cycle progression, whereas $c 9, t 11$-CLA had no effect. The induced profile of $t 10, c 12$-CLA was determined by the down-regulation of cyclins and the up-regulation of p21(CIP1/WAF), which followed by the decreased activity of CDKs [63]. Another study described the antiproliferative activity of the two most abundant isomers of CLA on PC-3 prostate cancer cells. Ochoa et al. proved a significant decrease in PC-3 proliferation elicited by CLA with effectivity of $55 \%$ inhibition by $t 10, c 12$-CLA. Also, the levels on bcl-2 gene expression were decreased, while the level of cell cycle control p21(WAF1/Cip1) mRNA were increased. On the contrary, the effects of $c 9, t 11$-CLA did not show any significant result on the proteins cells but a moderate effect on the 5-LOX expression and on COX-2 inhibitors [64]. Another report that resembled the antiproliferative effects of CLA isomers was presented. Comparisons were made between $c 9$, t11-CLA, $c 9, c 11$-CLA and $t 10, c 12$-CLA in prostate (PC-3) and colorectal (HT-29, MIP-101) cancer cells. The cells were adapted in serum free medium to prevent the interference of the polyunsaturated fatty acids long chain. The results showed that $t 10, c 12$-CLA had more potent effects on the apoptosis in the MIP-101 and PC-3 cells, while $c 9, t 11$-CLA isomer had weaker effects. The difference among the individual isomer effects on cancer cell proliferation was explained by the geometric and positional configuration of the double bonds [49].

\subsection{Liver Cancer}

CLA has been proved to have anti-mutagenic and anti-carcinogenic properties on rat hepatoma dRLh-84 cells in vitro. It has been reported previously that the different anti-tumor behavior of the two major CLA isomers was a result of their geometrical inequality. Another study showed the differences in cytotoxic effects of CLA isomers on dRLh-84 rat hepatoma cell line [65]. The apoptotic effect supported by sub-G1 population accompanied with a time-dependent cleavage of poly (ADP-ribose) polymerase was higher in dRLh- 84 cells treated with $t 10, c 12$-CLA. The data also indicated that $t 10, c 12$-CLA 
could induce DNA fragmentation. Another follow up study confirmed the antimutagenic activity of $t 10, c 12$-CLA compared with other isomers $c 9, t 11$-CLA, $t 9, t 11$-CLA and $c 9$, c11-CLA. The cytotoxic effects in dRLh-84 rat hepatoma cells were triggered by $t 10, c 12$ CLA which induced mitochondrial apoptotic cell death. The t10, c12-CLA also induced lysosomal destabilization in the rat hepatoma cells [66]. Muzio et al. described the anticancer properties of CLA found in dairy products. CLA induced apoptosis in human hepatoma SK-HEP-1 cancer cells by different apoptotic pathways (increasing PPAR $\alpha$, and proapoptotic proteins). The link between PPAR $\alpha$ and proapoptotic proteins was given by the induction of protein phosphatase 2 enzyme (PP2A), whose genes contained putative PPRE sequences [67]. It has been reported the anti-cancer effects on human liver cancer cell line HepG2 under condition containing $1 \% \mathrm{O}_{2}$. Both isomers $c 9, t 11$-CLA and $t 10$, c12-CLA inhibited cell proliferation and induced apoptotic cell death under the low oxygen conditions (HIF- $1 \alpha$ stabilization). Since the detailed mechanism remained unexplained, this unique study was shown to be of a great potential for future experiments [68].

\subsection{Skin Cancer}

There has been a sparse knowledge of CLA inhibitory effects against skin cancer cells. One study has demonstrated the anti-tumor promotion of CLA in skin keratinocytes (HEL$30)$ cells. Liu et al. pre-labeled the epidermal keratinocyte cells HEL-30 with radioactive $\left(1-{ }^{14} \mathrm{C}\right) \mathrm{CLA},\left(1-{ }^{14} \mathrm{C}\right) \mathrm{LA}$ and arachidonic acid $\left(1-{ }^{14} \mathrm{C}\right) \mathrm{AA}$ treated with tumor promoter (TPA). The cells were mixed in serum-free media with $0.1 \%$ bovine serum albumin (BSA). The results did not give any significant difference among the radiolabeled substrates on the cellular uptake. The evidence suggested that fatty acids played an equal important role in carcinogenesis and particularly in TPA-induced ornithine decarboxylase (ODC) activity and skin tumor promotion [69].

\section{Clinical Studies}

There have been few studies that have evaluated the effects of CLA in humans [70-72]. In this section we will summarize the effects of CLA on tumor incidence among different human tissues.

\subsection{Colon Cancer}

The anti-inflammatory properties of CLA have been investigated in the epidemiological human study to demonstrate the effects of mixed CLA isomers supplementation (50:50 $c 9, t 11$ and $t 10, c 12-C L A)$ in colorectal cancer patients undergoing chemoradiothetrapy. Mohammadzadeh et al. demonstrated that CLA cancer patients that received CLA supplements for 6 weeks reduced the tumor necrosis factor (TNF- $\alpha$ ) by improving the inflammatory factors matrix metalloproteinase (MMP-2 and MMP-9) compared with the placebo patients [73]. Another study suggested the consumption of high-fat dairy foods (containing CLA) had an association with colorectal cancer in women. The everyday intake of high-fat dairy food decreased the risk of colorectal cancer by $13 \%$ and the risk of distal colon cancer was decreased by $34 \%$ [74].

\subsection{Breast Cancer}

There have been few studies on the correlation of CLA dietary intake with human breast cancer incidences [75]. In postmenopausal women, dietary CLA reduced the levels of carcinogenesis. Women that consumed lower levels of CLA had a 3.3-fold greater risk of breast cancer than women who consumed higher level [76]. This study was inspired by previous findings that breast cancer incidence was reduced in women with high dietary milk consumption [77]. In another study, Chajes et al. demonstrated that there was no connection between CLA dietary intake and breast cancer. However, the hypothesis remained and more investigation was needed to prove the CLA protective effect on the cancer metastasis [78]. Another epidemiological study suggested the potential anticarcinogenic properties of CLA present in milk products. Voorrips et al. studied the relation 
between CLA intake and breast cancer in 55-69 year old female patients for 6 years [79]. The study demonstrated a weak influence of CLA against breast cancer, but the results were considered as a positive contribution for the overall evidence on CLA against breast cancer. Another 2 case-control of clinical study among 1122 women with confirmed breast cancer was revealed. The study was administered by a self-questionnaires regarding the dietary uptake of CLA. There was no significant association between dietary CLA and the overall risk of premenopausal or postmenopausal breast cancer. However, in premenopausal women there was a reduced risk of estrogen receptor (ER) negative tumor. These findings could be the base for future studies to establish connection between CLA intake and tumor biology, at least in female breast cancer [80].

\section{Cellular Mechanisms by Which CLA May Inhibit Cancer}

Overall, data from various cancer studies on animal, cell and human tumorigenesis with CLA provided abundant evidence that CLA can act as an anti-cancer agent. The examples of potential mechanisms of action to elucidate the role of CLA in modulating carcinogenesis on the stages of initiation, promotion, and progression are explained below.

\subsection{Anti-Cancer Initiation}

The anti-cancer initiation action of CLA can be attributed to the DNA damage leading to mutagenesis. The results from testing the chemoprotective effects on animal cell lines in bladder (TSU-Pr1) showed that CLA decreased DNA synthesis and induced apoptosis in TSU-Pr1 cells. CLA was considered to act as an inhibitor of DNA synthesis [81]. Some studies originally believed that the anti-carcinogenic effects of CLA were due to its antioxidant activity. They reported the antioxidant activity of CLA by tracking the inhibition of CLA on the chelation of iron by $\beta$-hydroxy derivatives (Fenton reaction - catalysis of hydrogen peroxide) $[14,15,82]$. In more recent study, Yu et al. demonstrated the protective effect of CLA against free scavenging radicals [83]. Another hypothesis suggested that the anti-carcinogenic activity of CLA was due to its antioxidant properties, promoting the in situ defense mechanism against free radical attacks on the cell membrane [84]. The supplementation of $\beta$-carotene in combination with CLA may be cytotoxic to human malignant melanoma and breast cancer cells in vitro [85]. CLA performed in vitro antioxidant activity by protecting the cells from peroxidation $[83,85]$. These results did not give any strong evidence and therefore it has not been conclusively established whether CLA works as an antioxidant. Further study is needed to resolve the relationship between the anti-cancer effects and antioxidant activity of CLA.

\subsection{Anti-Cancer Promotion}

The anti-promotional activity of CLA against cancer has been evaluated in several studies. The results suggested few potential mechanisms between CLA and animal/cell studies are likely to be involved: alternation of eicosanoid metabolism (COX-2, 5-LOX), induction of apoptosis (bcl-2), cell proliferation (c-myc), effects of PPAR. Belury et al. suggested that CLA affects the composition of cell membrane, which, in turn alters eicosanoid synthesis [86]. Other few studies also suggested that CLA acts as a preventive agent on eicosanoid metabolism which have focus on tumor induction [87]. The reduction of eicosanoid was also monitored by the inhibition of the glycoprotein enzyme COX, responsible for the synthesis of prostaglandins and thromboxanes from arachidonic acid. Urquhart et al. investigated the role of CLA in the regulation of eicosanoid synthesis. They used selective inhibitor (indomethacin) for COX-1 and incubated on human saphenous vein endothelial cells (HSVEC) with CLA (50:50, mixture of $c 9, t 11$ and $t 10, c 12-C L A)$. The addition of CLA to HSVEC cells resulted in inhibition of eicosanoid production, suggesting that the cancer preventive role of CLA in carcinogenesis was mediated through the inhibition of COX-1. The CLA mixture proved its beneficial anti-inflammatory effects that contributed to its anti-carcinogenic properties [87]. 


\subsection{Anti-Proliferative}

Previous studies in this report have documented the anti-proliferative properties of CLA. Tumorigenesis can be reduced by inhibiting the cell growth or by increasing apoptosis. CLA has been demonstrated to stimulate the accumulation of proteins such as p27, p53 and p21, which have an additional role in tumor suppression $[29,88,89]$. Previously, CLA was presented to induce several tumors present in mammary, breast, colon and prostate tissues. The biochemical and molecular mechanisms to describe its anti-tumor effects have been suggested, but at the cellular level, exclusion of cancerous cells was manifested through a process of programmed cell death, called apoptosis [23,58,90,91]. Apoptosis depends on the activity of the Bcl-2 regulator proteins which are believed to work as an apoptosis "suppressor gene" [92]. In mitochondria, the release of cytochrome $\mathrm{c}$ to the cytosol is partially controlled by members of the Bcl-2 family. They inhibit the onset of apoptosis by blockage of the protein-conducting channels. They select and maintain the long-living cells in the G0 phase of the cell cycle [93]. Previously, we reported that Bcl-2 expression was decreased in various tumor lesions of animals fed with CLA $[47,90]$. It was showed that CLA inhibited the proliferation of colon and prostate cancer cells through the induction of apoptosis, attributing to its ability to down-regulate ErbB3 signaling and PI3/Akt pathway [47,48]. Furthermore, another study demonstrated that CLA targeted Bcl-2 by triggering apoptosis of p53 mutant mammary tumor cells [94]. As follows, the antiproliferative effects of CLA appeared to be linked to the induction of apoptosis. In particular, we proposed a schematic model of the mechanism on CLA against carcinogenesis. It has been previously reported that CLA induced the lipid metabolism and activated a group of nuclear transcription factors (PPARn). We predicted a model of peroxisome proliferation induced by CLA which resulted in apoptosis. The model was inspired by CLA inhibition in hepatic tumor cells lines (Figure 2). More details on the effects of each individual molecule can be found in the experimental studies [65-68].

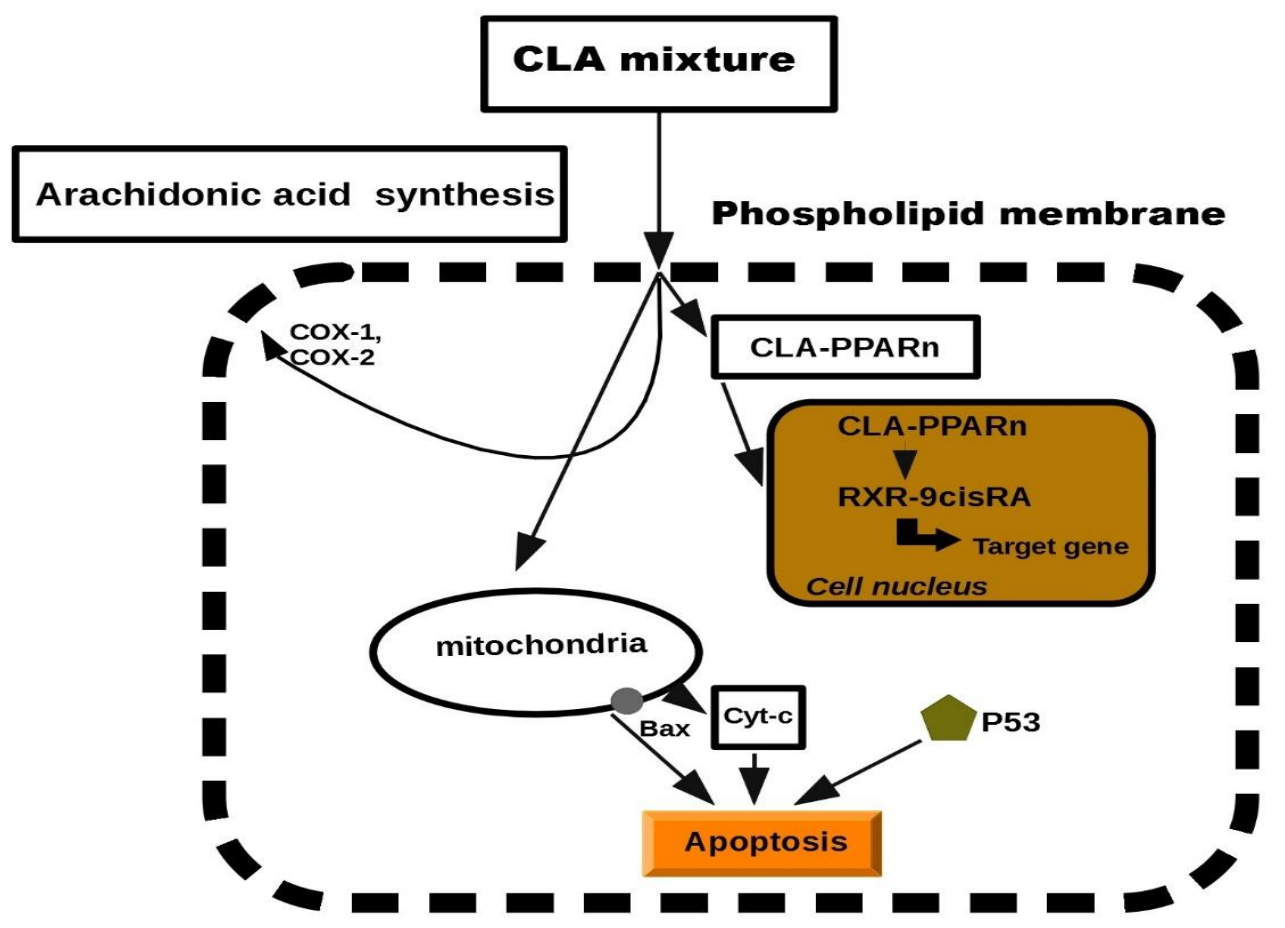

Figure 2. Schematic model of cell apoptosis induced by CLA.

\section{Discussion}

Early studies suggested that CLA treated mice had lower tumor incidence compared with control mice [15]. This has received a significant attention from researchers across the world prompting them to continue the investigation of the CLA isomers in animal and 
cell models. The anti-cancer activity of CLA has always been of particular interest, since its inhibitory effects were proved against different types of carcinogenesis at low dietary levels (for example 1\%). The studies from cell and animal models showed that CLA and individual isomers $(c 9, t 11$ and $t 10, c 12)$ seemed to lack scientific basis, because the results demonstrated in this review showed that different CLA isomers act through different mechanisms and have different effects. More control studies are necessary to be done to determine exactly which CLA isomer and concentration is responsible for particular cancer. Compared to cell and animal studies, there are insufficient proves of CLA against human cancer. Indeed in humans, the anti-carcinogenic effects of CLA have been attributed to their antioxidant activity. The combination of $\beta$-carotene with CLA inhibited the growth of cancer cells [84]. CLA performed was showed to conduct antioxidant properties by protecting the membranes from oxidative stress [85]. However, strong evidence was lacking to substantiate that CLA is a real antioxidant. CLA has been few times reported to potentially inhibit human cancer provided by natural sources of diet, such as milk, meat and cheese. Dairy products that are enriched in CLA isomers are of special interest to the food industry. For example, high concentration of vaccenic acid is an intermediate in the bio hydrogenation of LA in the rumen and high concentration can be found in milk [95]. Miller et al. demonstrated that vaccenic acid (VA) was converted to $c 9, t 11$-CLA in mammary (MCF-7) and colon (SW480) cancer cells via the fatty acid desaturase ( $\triangle 9$-) reaction [96]. This study evaluated the practicality of using VA as a precursor for the synthesis of $c 9$, t11-CLA in achieving cancer protection. As a result, these experiments opened another field of research whether additional CLA metabolites can be responsible for the anti-cancer effects of CLA or perhaps a future anti-cancer molecule. Nevertheless, there are variations within studies of CLA and its anti-cancer beneficial effects seen in some cells and animals, have not been manifested in human studies. The differences in dosage and the source of CLA can also contribute to this variety of results. There are few models presented that CLA has no effect on cancer inhibition, and a few have even shown that CLA enhances tumorigenesis $[26,97,98]$. The mechanism of these actions needs to be further investigated.

\section{Conclusions}

Our review analyzed several types of cancers, originating from different in vivo and in vitro models, to examine their response to CLA treatment and to demonstrate the involvement of CLA in controlling tumorigenesis. Various studies mainly from cell and animal models indicates that CLA and individual isomers $(c 9, t 11$ and $t 10, c 12)$ may have diverse beneficial effects against cancer. Moreover, there are variations between studies, and the inhibitory effects seen in some cell or animal models have not been reproduced in clinical studies. This can be attributed to difference in dosage of CLA uptake and differences in the chemical nature of the isomers $(c 9, t 11$ and $t 10, c 12)$. Overall, the information described in this review gives us a hint about the potential of CLA against the effects of cancer and provides information about the usage of CLA in chemoprevention of different cancers. The public interest of CLA is growing and more clinical studies are needed in order to elucidate the anti-cancer efficiency. The FDA is considering CLA as a possible supplement or food additive for the means of preventing cancer in future.

Author Contributions: Conceptualization, M.D. and J.B.; methodology, M.D., J.B. and Z.M.; software, J.B.; resources, M.J.; validation, M.D. and J.B.; writing—original draft preparation, M.D.; writingreview and editing, M.U.; visualization, M.D., Z.M., J.B. and M.U.; supervision, M.U. and M.J.; project administration, M.U. and M.J.; funding acquisition, M.J. All authors have read and agreed to the published version of the manuscript.

Funding: This work was supported by METROFOOD-CZ project MEYS Grant No: LM2018100 and by the Ministry of Agriculture of the Czech Republic, institutional support MZE-RO0318.

Institutional Review Board Statement: The study was conducted according to the guidelines of the Declaration of Helsinki, and approved by the Institutional Review Board of Food Research Institute Prague. 
Informed Consent Statement: Informed consent was obtained from all subjects involved in the study.

Data Availability Statement: The authors confirm that the data supporting the findings of this study are available within the article.

Conflicts of Interest: The authors have no conflict of interest to disclose.

\section{References}

1. Ander, B.P.; Dupasquier, C.M.; Prociuk, M.A.; Pierce, G.N. Polyunsaturated fatty acids and their effects on cardiovascular disease. Exp. Clin. Cardiol. 2003, 8, 164-172.

2. Koba, K.; Yanagita, T. Health benefits of conjugated linoleic acid (CLA). Obes. Res. Clin. Pract. 2014, 8, e525-e532. [CrossRef] [PubMed]

3. Albers, R.; van der Wielen, R.P.; Brink, E.J.; Hendriks, H.F.; Dorovska-Taran, V.N.; Mohede, I.C. Effects of cis-9, trans-11 and trans-10, cis-12 conjugated linoleic acid (CLA) isomers on immune function in healthy men. Eur. J. Clin. Nutr. 2003, 57, 595-603. [CrossRef]

4. Salsinha, A.S.; Pimentel, L.L.; Fontes, A.L.; Gomes, A.M.; Rodríguez-Alcalá, L.M. Microbial Production of Conjugated Linoleic Acid and Conjugated Linolenic Acid Relies on a Multienzymatic System. Microbiol. Mol. Biol. Rev. 2018, 82, e00019-18. [CrossRef]

5. Kepler, C.R.; Tucker, W.P.; Tove, S.B. Biohydrogenation of Unsaturated Fatty Acids: V. Stereospecificity of proton addition and mechanism of action of linoleic acid $\Delta 12$-cis, $\Delta 11$-trans-isomerase from Butyrivibrio fibrisolvens. J. Biol. Chem. 1971, 246, 2765-2771. [CrossRef]

6. Gorissen, L.; Leroy, F.; De Vuyst, L.; De Smet, S.; Raes, K. Bacterial production of conjugated linoleic and linolenic Acid in foods: A technological challenge. Crit. Rev. Food Sci. Nutr. 2015, 55, 1561-1574. [CrossRef] [PubMed]

7. Lee, S.O.; Kim, C.S.; Cho, S.K.; Choi, H.J.; Ji, G.E.; Oh, D.-K. Bioconversion of linoleic acid into conjugated linoleic acid during fermentation and by washed cells of Lactobacillus reuteri. Biotechnol. Lett. 2003, 25, 935-938. [CrossRef] [PubMed]

8. Lin, M.-Y.; Yen, C.-L. Inhibition of Lipid Peroxidation by Lactobacillus acidophilus and Bifidobacterium longum. J. Agric. Food Chem. 1999, 47, 3661-3664. [CrossRef]

9. Dahiya, D.K.; Puniya, A.K. Isolation, molecular characterization and screening of indigenous lactobacilli for their abilities to produce bioactive conjugated linoleic acid (CLA). J. Food Sci. Technol. 2017, 54, 792-801. [CrossRef]

10. Chung, S.H.; Kim, I.H.; Park, H.G.; Kang, H.S.; Yoon, C.S.; Jeong, H.Y.; Choi, N.J.; Kwon, E.G.; Kim, Y.J. Synthesis of Conjugated Linoleic Acid by Human-Derived Bifidobacterium breve LMC 017: Utilization as a Functional Starter Culture for Milk Fermentation. J. Agric. Food Chem. 2008, 56, 3311-3316. [CrossRef]

11. Dhiman, T.R.; Nam, S.H.; Ure, A.L. Factors affecting conjugated linoleic acid content in milk and meat. Crit. Rev. Food Sci. Nutr. 2005, 45, 463-482. [CrossRef]

12. Yang, B.; Chen, H.; Stanton, C.; Ross, R.P.; Zhang, H.; Chen, Y.Q.; Chen, W. Review of the roles of conjugated linoleic acid in health and disease. J. Funct. Foods 2015, 15, 314-325. [CrossRef]

13. Booth, R.G.; Kon, S.A. A study of seasonal variation in butter fat: A seasonal spectroscopic variation in the fatty acid fraction. Biochem. J. 1935, 29, 133-137. [CrossRef]

14. Pariza, M.W.; Ashoor, S.H.; Chu, F.S. Mutagens in heat-processed meat, bakery and cereal products. Food Cosmet Toxicol. 1979, 17, 429-430. [CrossRef]

15. Ha, Y.L.; Grimm, N.K.; Pariza, M.W. Anticarcinogens from fried ground beef: Heat-altered derivatives of linoleic acid. Carcinogenesis 1987, 8, 1881-1887. [CrossRef] [PubMed]

16. Tanaka, K. Occurrence of conjugated linoleic acid in ruminant products and its physiological functions. Anim. Sci. J. 2005, 76, 291-303. [CrossRef]

17. Kelley, N.S.; Hubbard, N.E.; Erickson, K.L. Conjugated linoleic acid isomers and cancer. J. Nutr. 2007, 137, 2599-2607. [CrossRef] [PubMed]

18. Lee, K.W.; Lee, H.J.; Cho, H.Y.; Kim, Y.J. Role of the conjugated linoleic acid in the prevention of cancer. Crit. Rev. Food Sci. Nutr. 2005, 45, 135-144. [CrossRef]

19. Khanal, R. Potential health benefits of conjugated linoleic acid (CLA): A Review. Anim. Biosci. 2004, 17, 1315-1328. [CrossRef]

20. Den Hartigh, L.J. Conjugated linoleic acid effects on cancer, obesity, and atherosclerosis: A review of pre-clinical and human trials with current perspectives. Nutrients. 2019, 11, 370. [CrossRef]

21. Pariza, M.W.; Hargraves, W.A. A beef-derived mutagenesis modulator inhibits initiation of mouse epidermal tumors by 7,12dimethylbenz[a]anthracene. Carcinogenesis 1985, 6, 591-593. [CrossRef] [PubMed]

22. Azain, M.J. Conjugated linoleic acid and its effects on animal products and health in single-stomached animals. Proc. Nutr Soc. 2003, 62, 319-328. [CrossRef] [PubMed]

23. Park, H.S.; Ryu, J.H.; Ha, Y.L.; Park, J.H.Y. Dietary conjugated linoleic acid (CLA) induces apoptosis of colonic mucosa in 1,2-dimethylhydrazine-treated rats: A possible mechanism of the anticarcinogenic effect by CLA. Br. J. Nutr. 2001, 86, 549-555. [CrossRef] 
24. Shiraishi, R.; Iwakiri, R.; Fujise, T.; Kuroki, T.; Kakimoto, T.; Takashima, T.; Sakata, Y.; Tsunada, S.; Nakashima, Y.; Yanagita, T.; et al. Conjugated linoleic acid suppresses colon carcinogenesis in azoxymethane-pretreated rats with long-term feeding of diet containing beef tallow. J. Gastroenterol. 2010, 45, 625-635. [CrossRef] [PubMed]

25. Mandir, N.; Goodlad, R.A. Conjugated linoleic acids differentially alter polyp number and diameter in the Apcmin/+ mouse model of intestinal cancer. Cell Prolif. 2008, 41, 279-291. [CrossRef] [PubMed]

26. Petrik, M.B.; McEntee, M.F.; Johnson, B.T.; Obukowicz, M.G.; Whelan, J. Highly unsaturated (n-3) fatty acids, but not alphalinolenic, conjugated linoleic or gamma-linolenic acids, reduce tumorigenesis in Apc(Min/+) mice. J. Nutr. 2000, 130, 2434-2443. [CrossRef]

27. Soel, S.M.; Choi, O.S.; Bang, M.H.; Yoon Park, J.H.; Kim, W.K. Influence of conjugated linoleic acid isomers on the metastasis of colon cancer cells in vitro and in vivo. J. Nutr. Biochem. 2007, 18, 650-657. [CrossRef]

28. Nichenametla, S.; South, E.; Exon, J. Interaction of conjugated linoleic acid, sphingomyelin, and butyrate on formation of colonic aberrant crypt foci and immune functions in rats. J. Toxicol. Env. Health A 2004, 67, 469-481. [CrossRef]

29. Kim, K.-H.; Park, H.-S. Dietary supplementation of conjugated linoleic acid reduces colon tumor incidence in DMH-treated rats by increasing apoptosis with modulation of biomarkers. Nutrition 2003, 19, 772-777. [CrossRef]

30. Sasaki, T.; Fujii, K.; Yoshida, K.; Shimura, H.; Sasahira, T.; Ohmori, H.; Kuniyasu, H. Peritoneal metastasis inhibition by linoleic acid with activation of PPARgamma in human gastrointestinal cancer cells. Virchows Arch. 2006, 448, 422-427. [CrossRef]

31. Ip, C.; Scimeca, J.A. Conjugated linoleic acid and linoleic acid are distinctive modulators of mammary carcinogenesis. Nutr Cancer 1997, 27, 131-135. [CrossRef]

32. Białek, M.; Białek, A.; Czauderna, M. Conjugated Linoleic Acid Isomers Affect Profile of Lipid Compounds and Intensity of Their Oxidation in Heart of Rats with Chemically-Induced Mammary Tumors-Preliminary Study. Nutrients 2019, 11, 2032. [CrossRef]

33. Visonneau, S.; Cesano, A.; Tepper, S.A.; Scimeca, J.A.; Santoli, D.; Kritchevsky, D. Conjugated linoleic acid suppresses the growth of human breast adenocarcinoma cells in SCID mice. Anticancer Res. 1997, 17, 969-973.

34. Hubbard, N.E.; Lim, D.; Summers, L.; Erickson, K.L. Reduction of murine mammary tumor metastasis by conjugated linoleic acid. Cancer Lett. 2000, 150, 93-100. [CrossRef]

35. Tao, X.M.; Wang, J.C.; Wang, J.B.; Feng, Q.; Gao, S.Y.; Zhang, L.R.; Zhang, Q. Enhanced anticancer activity of gemcitabine coupling with conjugated linoleic acid against human breast cancer in vitro and in vivo. Eur. J. Pharm Biopharm. 2012, 82, 401-409. [CrossRef]

36. Lavillonnière, F.; Chajès, V.; Martin, J.C.; Sébédio, J.L.; Lhuillery, C.; Bougnoux, P. Dietary purified cis-9,trans-11 conjugated linoleic acid isomer has anticarcinogenic properties in chemically induced mammary tumors in rats. Nutr. Cancer 2003, 45 , 190-194. [CrossRef] [PubMed]

37. Zeng, Y.; Liu, P.; Yang, X.; Li, H.; Li, H.; Guo, Y.; Meng, X.; Liu, X. The dietary c9, t11-conjugated linoleic acid enriched from butter reduces breast cancer progression in vivo. J. Food Biochem. 2020, 44, e13163. [CrossRef]

38. Ip, C.; Banni, S.; Angioni, E.; Carta, G.; McGinley, J.; Thompson, H.J.; Barbano, D.; Bauman, D. Conjugated Linoleic Acid-Enriched Butter Fat Alters Mammary Gland Morphogenesis and Reduces Cancer Risk in Rats. J. Nutr. 1999, 129, 2135-2142. [CrossRef]

39. Cesano, A.; Visonneau, S.; Scimeca, J.A.; Kritchevsky, D.; Santoli, D. Opposite effects of linoleic acid and conjugated linoleic acid on human prostatic cancer in SCID mice. Anticancer Res. 1998, 18, 1429-1434. [PubMed]

40. Yang, H.; Holcroft, J.; Glickman, B.W.; de Boer, J.G. Conjugated linoleic acid inhibits mutagenesis by 2-amino-1-methyl-6phenylimidazo[4,5-b]pyridine in the prostate of Big Blue rats. Mutagenesis 2003, 18, 195-200. [CrossRef]

41. Jung, M.Y.; Choi, N.J.; Oh, C.H.; Shin, H.K.; Yoon, S.H. Selectively Hydrogenated Soybean Oil Exerts Strong Anti-Prostate Cancer Activities. Lipids 2011, 46, 287-295. [CrossRef] [PubMed]

42. Cohen, L.A.; Zhao, Z.; Pittman, B.; Scimeca, J. Effect of soy protein isolate and conjugated linoleic acid on the growth of Dunning R-3327-AT-1 rat prostate tumors. Prostate 2003, 54, 169-180. [CrossRef] [PubMed]

43. Kilian, M.; Mautsch, I.; Gregor, J.I.; Stahlknecht, P.; Jacobi, C.A.; Schimke, I.; Guski, H.; Wenger, F.A. Influence of conjugated vs. conventional linoleic acid on liver metastasis and hepatic lipidperoxidation in BOP-induced pancreatic cancer in Syrian hamster. Prostaglandins Leukot Essent Fat. Acids 2002, 67, 223-228. [CrossRef] [PubMed]

44. Kilian, M.; Mautsch, I.; Gregor, J.I.; Heinichen, D.; Jacobi, C.A.; Schimke, I.; Guski, H.; Müller, J.M.; Wenger, F.A. Influence of conjugated and conventional linoleic acid on tumor growth and lipid peroxidation in pancreatic adenocarcinoma in hamster. Prostaglandins Leukot Essent Fat. Acids 2003, 69, 67-72. [CrossRef]

45. Kohno, H.; Suzuki, R.; Yasui, Y.; Hosokawa, M.; Miyashita, K.; Tanaka, T. Pomegranate seed oil rich in conjugated linolenic acid suppresses chemically induced colon carcinogenesis in rats. Cancer Sci. 2004, 95, 481-486. [CrossRef] [PubMed]

46. Yamasaki, M.; Ikeda, A.; Hirao, A.; Tanaka, Y.; Miyazaki, Y.; Rikimaru, T.; Shimada, M.; Sugimachi, K.; Tachibana, H.; Yamada, K. Effect of dietary conjugated linoleic acid on the in vivo growth of rat hepatoma dRLh-84. Nutr. Cancer 2001, 40, 140-148. [CrossRef]

47. Cho, H.J.; Kim, W.K.; Kim, E.J.; Jung, K.C.; Park, S.; Lee, H.S.; Tyner, A.L.; Park, J.H.Y. Conjugated linoleic acid inhibits cell proliferation and ErbB3 signaling in HT-29 human colon cell line. Am. J. Physiol. Gastrointest. Liver Physiol. 2003, 284, G996-G1005. [CrossRef]

48. Cho, H.J.; Kim, W.K.; Jung, J.I.; Kim, E.J.; Lim, S.S.; Kwon, D.Y.; Park, J.H. Trans-10,cis-12, not cis-9, trans-11, conjugated linoleic acid decreases ErbB3 expression in HT-29 human colon cancer cells. World J. Gastroenterol. 2005, 11, 5142-5150. 
49. Palombo, J.D.; Ganguly, A.; Bistrian, B.R.; Menard, M.P. The antiproliferative effects of biologically active isomers of conjugated linoleic acid on human colorectal and prostatic cancer cells. Cancer Lett. 2002, 177, 163-172. [CrossRef]

50. Kim, E.J.; Holthuizen, P.E.; Park, H.S.; Ha, Y.L.; Jung, K.C.; Park, J.H.Y. Trans-10,cis-12-conjugated linoleic acid inhibits Caco-2 colon cancer cell growth. Am. J. Physiol. Gastrointest. Liver Physiol. 2002, 283, G357-G367. [CrossRef]

51. Lampen, A.; Leifheit, M.; Voss, J.; Nau, H. Molecular and cellular effects of cis-9, trans-11-conjugated linoleic acid in enterocytes: Effects on proliferation, differentiation, and gene expression. Biochim. Biophys. Acta (Bba) Mol. Cell Biol. Lipids 2005, 1735, 30-40. [CrossRef] [PubMed]

52. Lim, D.Y.; Tyner, A.L.; Park, J.-B.; Lee, J.-Y.; Choi, Y.H.; Park, J.H.Y. Inhibition of colon cancer cell proliferation by the dietary compound conjugated linoleic acid is mediated by the CDK inhibitor p21CIP1/WAF1. J. Cell. Physiol. 2005, 205, 107-113. [CrossRef] [PubMed]

53. Chen, B.Q.; Yang, Y.M.; Wang, Q.; Gao, Y.H.; Liu, J.R.; Zhang, J.S.; Wang, X.L.; Liu, R.H. Effects of c9, t11-conjugated linoleic acid on adhesion of human gastric carcinoma cell line SGC-7901. World J. Gastroenterol. 2004, 10, 1392-1396. [CrossRef] [PubMed]

54. Wang, L.S.; Huang, Y.W.; Liu, S.; Chang, H.L.; Ye, W.; Shu, S.; Sugimoto, Y.; Funk, J.A.; Smeaks, D.D.; Hill, L.N.; et al. Conjugated linoleic acid (CLA) modulates prostaglandin E2 (PGE2) signaling in canine mammary cells. Anticancer Res. 2006, $26,889-898$.

55. Sorenmo, K. Canine mammary gland tumors. Vet. Clin. N. Am. Small Anim Pr. 2003, 33, 573-596. [CrossRef]

56. O'Shea, M.; Devery, R.; Lawless, F.; Murphy, J.; Stanton, C. Milk fat conjugated linoleic acid (CLA) inhibits growth of human mammary MCF-7 cancer cells. Anticancer Res. 2000, 20, 3591-3601. [PubMed]

57. El Roz, A.; Bard, J.M.; Huvelin, J.M.; Nazih, H. The anti-proliferative and pro-apoptotic effects of the trans9,trans11 conjugated linoleic acid isomer on MCF-7 breast cancer cells are associated with LXR activation. Prostaglandins Leukot. Essent. Fat. Acids 2013, 88, 265-272. [CrossRef]

58. Miglietta, A.; Bozzo, F.; Bocca, C.; Gabriel, L.; Trombetta, A.; Belotti, S.; Canuto, R.A. Conjugated linoleic acid induces apoptosis in MDA-MB-231 breast cancer cells through ERK/MAPK signalling and mitochondrial pathway. Cancer Lett. 2006, 234, 149-157. [CrossRef]

59. Durgam, V.R.; Fernandes, G. The growth inhibitory effect of conjugated linoleic acid on MCF-7 cells is related to estrogen response system. Cancer Lett. 1997, 116, 121-130. [CrossRef]

60. Park, Y.; Allen, K.G.; Shultz, T.D. Modulation of MCF-7 breast cancer cell signal transduction by linoleic acid and conjugated linoleic acid in culture. Anticancer Res. 2000, 20, 669-676.

61. Rakib, M.A.; Kim, Y.S.; Jang, W.J.; Choi, B.D.; Kim, J.O.; Kong, I.K.; Ha, Y.L. Attenuation of 12-O-Tetradecanoylphorbol-13-acetate (TPA)-Induced Gap Junctional Intercellular Communication (GJIC) Inhibition in MCF-10A Cells by c9, t11-Conjugated Linoleic Acid. J. Agric. Food Chem. 2010, 58, 12022-12030. [CrossRef]

62. Rakib, M.A.; Kim, Y.S.; Jang, W.J.; Jang, J.S.; Kang, S.J.; Ha, Y.L. Preventive Effect of t,t-Conjugated Linoleic Acid on 12-OTetradecanoylphorbol-13-acetate-Induced Inhibition of Gap Junctional Intercellular Communication in Human Mammary Epithelial MCF-10A Cells. J. Agric. Food Chem. 2011, 59, 4164-4170. [CrossRef]

63. Kim, E.J.; Shin, H.-K.; Cho, J.S.; Lee, S.K.; Won, M.H.; Kim, J.W.; Park, J.H.Y. trans-10,cis-12 Conjugated Linoleic Acid Inhibits the G1-S Cell Cycle Progression in DU145 Human Prostate Carcinoma Cells. J. Med. Food 2006, 9, 293-299. [CrossRef]

64. Ochoa, J.J.; Farquharson, A.J.; Grant, I.; Moffat, L.E.; Heys, S.D.; Wahle, K.W.J. Conjugated linoleic acids (CLAs) decrease prostate cancer cell proliferation: Different molecular mechanisms for cis -9 , trans -11 and trans -10 , cis -12 isomers. Carcinogenesis 2004, 25, 1185-1191. [CrossRef]

65. Yamasaki, M.; Chujo, H.; Koga, Y.; Oishi, A.; Rikimaru, T.; Shimada, M.; Sugimachi, K.; Tachibana, H.; Yamada, K. Potent cytotoxic effect of the trans10, cis12 isomer of conjugated linoleic acid on rat hepatoma dRLh-84 cells. Cancer Lett. 2002, 188, 171-180. [CrossRef]

66. Yamasaki, M.; Miyamoto, Y.; Chujo, H.; Nishiyama, K.; Tachibana, H.; Yamada, K. Trans10, cis12-conjugated linoleic acid induces mitochondria-related apoptosis and lysosomal destabilization in rat hepatoma cells. Biochim. Biophys. Acta (Bba) Mol. Cell Biol. Lipids 2005, 1735, 176-184. [CrossRef] [PubMed]

67. Muzio, G.; Maggiora, M.; Oraldi, M.; Trombetta, A.; Canuto, R.A. PPAR $\alpha$ and PP2A are involved in the proapoptotic effect of conjugated linoleic acid on human hepatoma cell line SK-HEP-1. Int. J. Cancer 2007, 121, 2395-2401. [CrossRef]

68. Yamasaki, M.; Nagatomo, T.; Matsuyama, T.; Ikeho, Y.; Kato, E.; Nishiyama, K.; Sakakibara, Y.; Suiko, M.; Nishiyama, K. Conjugated linoleic acids inhibit hypoxia inducible factor- $1 \alpha$ stabilization under hypoxic condition in human hepatocellular carcinoma cells. J. Oleo Sci. 2012, 61, 491-496. [CrossRef]

69. Liu, K.L.; Belury, M.A. Conjugated linoleic acid modulation of phorbol ester-induced events in murine keratinocytes. Lipids 1997, 32, 725-730. [CrossRef] [PubMed]

70. McCrorie, T.A.; Keaveney, E.M.; Wallace, J.M.W.; Binns, N.; Livingstone, M.B.E. Human health effects of conjugated linoleic acid from milk and supplements. Nutr. Res. Rev. 2011, 24, 206-227. [CrossRef] [PubMed]

71. Bhattacharya, A.; Banu, J.; Rahman, M.; Causey, J.; Fernandes, G. Biological effects of conjugated linoleic acids in health and disease. J. Nutr. Biochem. 2006, 17, 789-810. [CrossRef] [PubMed]

72. Moon, H.-S. Biological effects of conjugated linoleic acid on obesity-related cancers. Chem. Biol. Interact. 2014, 224, 189-195. [CrossRef] [PubMed] 
73. Mohammadzadeh, M.; Faramarzi, E.; Mahdavi, R.; Nasirimotlagh, B.; Asghari, J.M. Effect of conjugated linoleic acid supplementation on inflammatory factors and matrix metalloproteinase enzymes in rectal cancer patients undergoing chemoradiotherapy. Integr Cancer Ther. 2013, 12, 496-502. [CrossRef] [PubMed]

74. Larsson, S.C.; Bergkvist, L.; Wolk, A. High-fat dairy food and conjugated linoleic acid intakes in relation to colorectal cancer incidence in the Swedish Mammography Cohort. Am J Clin Nutr. 2005, 82, 894-900. [CrossRef]

75. Arab, A.; Akbarian, S.G.; Ghiyasvand, R.; Miraghajani, M. The effects of conjugated linoleic acids on breast cancer: A systematic review. Adv. Biomed. Res. 2016, 5, 115. [PubMed]

76. Aro, A.; Männistö, S.; Salminen, I.; Ovaskainen, M.L.; Kataja, V.; Uusitupa, M. Inverse association between dietary and serum conjugated linoleic acid and risk of breast cancer in postmenopausal women. Nutr. Cancer 2000, 38, 151-157. [CrossRef]

77. Knekt, P.; Järvinen, R.; Seppänen, R.; Pukkala, E.; Aromaa, A. Intake of dairy products and the risk of breast cancer. Br. J. Cancer 1996, 73, 687-691. [CrossRef]

78. Chajes, V.; Lavillonniere, F.; Maillard, V.; Giraudeau, B.; Jourdan, M.L.; Sebedio, J.L.; Bougnoux, P. Conjugated linoleic acid content in breast adipose tissue of breast cancer patients and the risk of metastasis. Nutr. Cancer 2003, 45, 17-23. [CrossRef]

79. Voorrips, L.E.; Brants, H.A.M.; Kardinaal, A.F.M.; Hiddink, G.J.; van den Brandt, P.A.; Goldbohm, R.A. Intake of conjugated linoleic acid, fat, and other fatty acids in relation to postmenopausal breast cancer: The Netherlands Cohort Study on Diet and Cancer. Am. J. Clin. Nutr. 2002, 76, 873-882. [CrossRef]

80. McCann, S.E.; Ip, C.; Ip, M.M.; McGuire, M.K.; Muti, P.; Edge, S.B.; Trevisan, M.; Freudenheim, J.L. Dietary intake of conjugated linoleic acids and risk of premenopausal and postmenopausal breast cancer, Western New York Exposures and Breast Cancer Study (WEB Study). Cancer Epidemiol. Biomark. Prev. 2004, 13, 1480-1484.

81. Oh, Y.S.; Lee, H.S.; Cho, H.J.; Lee, S.G.; Jung, K.C.; Park, J.H. Conjugated linoleic acid inhibits DNA synthesis and induces apoptosis in TSU-Pr1 human bladder cancer cells. Anticancer Res. 2003, 23, 4765-4772.

82. Ha, Y.L.; Storkson, J.; Pariza, M.W. Inhibition of benzo(a)pyrene-induced mouse forestomach neoplasia by conjugated dienoic derivatives of linoleic acid. Cancer Res. 1990, 50, 1097-1101.

83. Yu, L. Free Radical Scavenging Properties of Conjugated Linoleic Acids. J. Agric. Food Chem. 2001, 49, 3452-3456. [CrossRef] [PubMed]

84. Shultz, T.D.; Chew, B.P.; Seaman, W.R.; Luedecke, L.O. Inhibitory effect of conjugated dienoic derivatives of linoleic acid and beta-carotene on the in vitro growth of human cancer cells. Cancer Lett. 1992, 63, 125-133. [CrossRef]

85. Lalithadevi, B.; Muthiah, N.S.; Murty, K.S.N. Antioxidant activity of conjugated linoleic acid. Asian J. Pharm. Clin. Res. 2018, 11, 169.

86. Belury, M.A.; Kempa-Steczko, A. Conjugated linoleic acid modulates hepatic lipid composition in mice. Lipids 1997, 32, 199-204. [CrossRef] [PubMed]

87. Urquhart, P.; Parkin, S.M.; Rogers, J.S.; Bosley, J.A.; Nicolaou, A. The effect of conjugated linoleic acid on arachidonic acid metabolism and eicosanoid production in human saphenous vein endothelial cells. Biochim. Biophys Acta 2002, 1580, 150-160. [CrossRef]

88. Kemp, M.Q.; Jeffy, B.D.; Romagnolo, D.F. Conjugated linoleic acid inhibits cell proliferation through a p53-dependent mechanism: Effects on the expression of G1-restriction points in breast and colon cancer cells. J. Nutr. 2003, 133, 3670-3677. [CrossRef] [PubMed]

89. Cho, H.J.; Kim, E.J.; Lim, S.S.; Kim, M.K.; Sung, M.K.; Kim, J.S.; Park, J.H. Trans-10,cis-12, not cis-9, trans-11, conjugated linoleic acid inhibits G1-S progression in HT-29 human colon cancer cells. J. Nutr. 2006, 136, 893-898. [CrossRef]

90. Ip, C.; Ip, M.M.; Loftus, T.; Shoemaker, S.; Shea-Eaton, W. Induction of apoptosis by conjugated linoleic acid in cultured mammary tumor cells and premalignant lesions of the rat mammary gland. Cancer Epidemiol. Biomark. Prev. 2000, 9, 689-696.

91. Wang, L.S.; Huang, Y.W.; Liu, S.; Yan, P.; Lin, Y.C. Conjugated linoleic acid induces apoptosis through estrogen receptor alpha in human breast tissue. BMC Cancer 2008, 8, 208. [CrossRef] [PubMed]

92. Bostwick, D.G.; Meiers, I. Prostate. In Modern Surgical Pathology, 2nd ed.; Weidner, N., Cote, R., Suster, S., Weiss, L., Eds.; Saunders: Collingwood, ON, Canada, 2009; Volume 2, pp. 1121-1180.

93. Borner, C. The Bcl-2 protein family: Sensors and checkpoints for life-or-death decisions. Mol. Immunol. 2003, 39, 615-647. [CrossRef]

94. Ou, L.; Ip, C.; Lisafeld, B.; Ip, M.M. Conjugated linoleic acid induces apoptosis of murine mammary tumor cells via Bcl-2 loss. Biochem. Biophys. Res. Commun. 2007, 356, 1044-1049. [CrossRef] [PubMed]

95. Cichosz, G.; Czeczot, H.; Bielecka, M. The anticarcinogenic potential of milk fat. Ann. Agric. Env. Med. 2020, 27, 512-518. [CrossRef]

96. Miller, A.; McGrath, E.; Stanton, C.; Devery, R. Vaccenic acid (t11-18:1) is converted to c9, t11-CLA in MCF-7 and SW480 cancer cells. Lipids 2003, 38, 623-632. [CrossRef] [PubMed]

97. Ip, C.; Dong, Y.; Thompson, H.J.; Bauman, D.E.; Ip, M.M. Control of rat mammary epithelium proliferation by conjugated linoleic acid. Nutr. Cancer 2001, 39, 233-238. [CrossRef] [PubMed]

98. Wong, M.W.; Chew, B.P.; Wong, T.S.; Hosick, H.L.; Boylston, T.D.; Shultz, T.D. Effects of dietary conjugated linoleic acid on lymphocyte function and growth of mammary tumors in mice. Anticancer Res. 1997, 17, 987-993. [PubMed] 